\title{
RafałŁatka
}

\section{Kard. Wyszyński i abp Wojtyła w „grze" milenijnej władz Polski „ludowej”}

\begin{abstract}
Abstrakt: Celem poniższej analizy jest omówienie działań władz PRL w czasie przygotowań i obchodów milenijnych wobec dwóch ważnych hierarchów polskiego Kościoła: kard. Stefana Wyszyńskiego i abp. Karola Wojtyły. Opisano rolę obydwu biskupów w czasie Wielkiej Nowenny i głównych uroczystości milenijnych oraz dokonano ich porównania w świetle dokumentacji partyjno-państwowej.
\end{abstract}

Słow a klucz owe: kard. Stefan Wyszyński, abp Karol Wojtyła, millennium, obchody, działania władz.

Abstract: The purpose of the following analysis is to present the actions undertaken by the Polish People's Republic authorities during the preparations and celebrations of the millennium anniversary against two important hierarchs of the Catholic Church in Poland: Cardinal Stefan Wyszyński and Archbishop Karol Wojtyła. The author describes the role of two bishops during the 'Great Novena' and the year of the main millennium celebrations and compares them in the light of party and state documentations.

Key w or d s: Card. Stefan Wyszyński, Abp Karol Wojtyła, Millennium, celebrations, actions of the authorities.

\section{Wprowadzenie}

Literatura na temat Wielkiej Nowenny, obchodów milenijnych 1966 r. czy wreszcie kontrdziałań władz, które nie tylko przeszkadzały w świętowaniu tysiąclecia chrztu Polski, ale również przygotowały konkurencyjne uroczystości 
nazywane tysiącleciem państwa polskiego, systematycznie się rozszerza ${ }^{1}$. W swojej analizie chciałbym spojrzeć na pewien wycinek „milenijnej konfrontacji”, przedstawiając sposób działania władz wobec dwóch wielkich postaci polskiego Kościoła: kard. Stefana Wyszyńskiego i abp. Karola Wojtyły. Rzecz jasna rola obydwu hierarchów w przygotowywaniu i przeprowadzeniu obchodów milenijnych była zupełnie inna. Prymas to autor koncepcji oraz główny kreator działań kościelnych, podczas gdy we wzmiankowanym okresie bp/abp Wojtyła był jednym z ważnych wykonawców jego założeń, którego pozycja jednakże systematycznie się zwiększała. Jak odnotowano w analizie sporzadzonej w Urzędzie do spraw Wyznań (UdsW): „Jest rzeczą prawie pewna, że Wojtyła otrzyma kapelusz kardynalski, z tego względu nie powinniśmy robić nic, co pogłębiłoby jego niechęć i rezerwę w stosunku do nas, co blokowałby go z kard. Wyszyńskim"2.

Moja analiza będzie się składała z trzech części. W pierwszej omówię pozycje obydwu hierarchów w polskim Kościele i kalkulacje władz związane z wyborem bp. Wojtyły na stanowisko metropolity krakowskiego. W drugiej

${ }^{1}$ Wśród najważniejszych prac należy wymienić: P. Raina, „Te Deum” narodu polskiego. Obchody Tysiaclecia Chrztu Polski w świetle dokumentów kościelnych, Olsztyn 1991; Zapomniany rok 1966. W XXX rocznice obchodów Milenium Chrztu Polski, red. L. Mażewski, W. Turek, Gdańsk 1996; Uroczystości milenijne 1966 roku. Sprawozdania urzędów spraw wewnętrznych, Warszawa 1996; Obchody milenijne 1966 roku. W świetle dokumentów Ministerstwa Spraw Wewnętrznych, Warszawa 1998; P. Raina, Kardynat Wyszyński. Konflikty roku milenijnego 1966, Warszawa 2000; Millennium polskie. Walka o rzqd dusz, Warszawa 2002; B. Noszczak, „Sacrum” czy „profanum”? Spór o istotę obchodów Milenium polskiego (1949-1966), Warszawa 2002; Milenium czy Tysiaclecie, red. B. Noszczak, Warszawa 2006; A. Szot, K. Sychowicz, Białostockie millenium. Biatystok na milenijnym szlaku Obchody tysiaclecia chrztu Polski (1966 r.), Białystok 2006; D. Gucewicz, Próba sit? Rok 1966 w Gdańsku. Milenium kontra Tysiaclecie, Gdańsk 2014; Pót wieku Milenium. Religijne, polityczne i społeczne aspekty obchodów Tysiqclecia Chrztu Polski (1956-1966/1967). Studia i materiaty, red. B. Noszczak, Warszawa 2018. Zob. też: S. Wyszyński, Zapiski milenijne. Wybór z dziennika „Pro memoria" z lat 1965-1967, wybór i oprac. M. Okońska i in., Warszawa 2001. Niemniej w dalszym ciagu pozostają słabo rozpoznane obszary badawcze, przede wszystkim jeśli chodzi o przygotowania i przebieg uroczystości milenijnych na uchodźstwie. Na ten temat szerzej zob. J. Żaryn, Dzieje Kościoła katolickiego w Polsce (1944-1989), Warszawa 2003, s. 255-263; Obchody Millenium na Uchodźstwie. W 50. rocznicę, red. R. Łatka, J. Żaryn, Warszawa 2016.

2 Archiwum Akt Nowych w Warszawie (dalej: AAN), Urząd do spraw Wyznań (dalej: UdsW), 76/5, Działalność ks. Kardynała Wojtyły tom I, Charakterystyka abp. Karola Wojtyły metropolity krakowskiego, sporządzona przez A. P. 3 VII 1965, k. 6. Analogiczne spekulacje pojawiały się w dokumentacji aparatu represji. Zob. np.: Doniesienie TW ps. „Magister” zawierające informacje o działalności abp. Karola Wojtyły, Kraków, 9 XII 1965, w: Ku prawdzie i wolności. Komunistyczna bezpieka wobec kard. Karola Wojtyty, red. J. Marecki, F. Musiał, oprac. J. Marecki, M. Lasota, R. Szczęch, Kraków 2009, s. 286-287. Szerzej zob. M. Lasota, Działania aparatu PRL wobec kard. Karola Wojtyty w latach 1967-1978. Wybrane zagadnienia, w: Kościót katolicki w czasach komunistycznej dyktatury. Między bohaterstwem a agenturq. Studia i materiaty, t. III, red. J. Szczepaniak, M. Lasota, Kraków 2010, s. 9-10. 
zwrócę uwagę na działania władz odnoszące się do listu biskupów polskich do biskupów niemieckich, który był istotna inicjatywą związaną z przygotowaniem uroczystości tysiąclecia chrztu Polski. W trzeciej pokażę, jak w roku milenijnym rolę kard. Wyszyńskiego i abp. Wojtyły oceniały władze oraz jaka aktywność podjęły, by ograniczyć ich możliwości działania, a tym samym zadbać o to, by uroczystości milenijne nie miały tak uroczystego charakteru, jak zakładał Episkopat Polski. Rzecz jasna na tle tej wspomnianej analizy przedstawię stanowisko wobec obchodów obu hierarchów polskiego Kościoła.

\section{Kard. Wyszyński i bp/abp Wojtyła w optyce władz}

Pierwszą uroczystością związaną z planowanymi na $1966 \mathrm{r}$. obchodami milenijnymi było odnowienie Ślubów Jasnogórskich w sierpniu 1956 r., z ich najbardziej wymownym symbolem - pustym tronem Prymasa Polski, w tym czasie ciagle internowanego i pozbawionego możliwości wykonywania swojej funkcji. Symbol ten jest o tyle istotny, że towarzyszył on obchodom milenijnym jeszcze kilkukrotnie. Program Ślubów przygotował osobiście kard. Wyszyński, a na Jasną Górę przemyciła go do odczytania Maria Okońska, jedna z „Ósemek”. Prymas wydał konkretne instrukcje, z których wywiązali się biskupi i całe duchowieństwo, dzięki czemu uroczystości należy oceniać jako wielki sukces Kościoła, gdyż w zależności od szacunków w „ślubowaniu” brało udział od 300 tys. do miliona wiernych ${ }^{3}$.

Kolejnym sukcesem prymasa było zwolnienie $\mathrm{z}$ internowania na własnych warunkach, które w zasadniczy sposób poszerzyły możliwość działania Kościoła w kolejnych latach sprawowania funkcji I sekretarza Polskiej Zjednoczonej Partii Robotniczej (PZPR) przez Władysława Gomułkę ${ }^{4}$ Najważniejsze z nich to odwołanie dekretu o obsadzie stanowisk kościelnych z 1953 r. oraz powrót do diecezji aresztowanych i wygnanych biskupów i księży. Wspomniane ustępstwa władz miały charakter tymczasowy, gdyż już na przełomie 1957 i 1958 r. dygnitarze partyjni postanowili zaostrzyć politykę wyznaniowa, intensyfikując ponownie walkę z Kościołem. Prymas miał pełną świadomość, że nie należy żywić wielkich nadziei na trwałe odprężenie w relacjach wzajemnych oraz że

\footnotetext{
${ }^{3}$ Szerzej zob. J. Żaryn, Dzieje Kościoła..., s. 158-163. Jak trafnie podkreślił Jerzy Eisler: „Jakby [...] nie patrzeć na całą uroczystość, nie ulega watpliwości, że była ona nie tylko wielkim osobistym sukcesem kardynała Wyszyńskiego, lecz także momentem niezwykłym w dziejach katolicyzmu w Polsce". Cyt. za: J. Eisler, Pusty tron, w: idem, Co nam zostało z tamtych lat. Dziedzictwo PRL, Warszawa 2016, s. 198.

${ }^{4} \mathrm{Na}$ ten temat szerzej zob. A. Dudek, R. Gryz, Komuniści i Kościót w Polsce (1945-1989), Kraków 2006, s. 106-113; R. Łatka, Czy prymasa Wyszyńskiego możemy określać mianem realisty politycznego?, w: Realizm polityczny, red. R. Łatka, „Politeja” 2013, nr 25, s. 205-206; Ł. Marek, Priorytety polityki wyznaniowej wtadz w okresie Gomutki, w: Priorytety polityki wyznaniowej wtadz Polski „ludowej”, red. R. Łatka, „Glaukopis” 2016, nr 32, s. 257-261.
} 
władze wznowią swoją antykościelną aktywność, choć już przy użyciu nieco bardziej wysublimowanych metod ${ }^{5}$.

Bez wątpienia przyczyniło się do tego również rozpoczęcie Wielkiej Nowenny, gdyż władze dzięki działaniom operacyjnym znały plany prymasa. Jak trafnie zauważył Jan Żaryn: „ku wściekłości ekipy Gomułki Kościół stawiał się w roli opiekuna polskiego dziedzictwa, wobec którego komunizm ze swoją obca ideologia pozostawał przejściowym epizodem. Władze zdecydowały się, zatem na otwartą konfrontację z programem Wielkiej Nowenny, prowadzona równolegle środkami represyjnymi, jak i kontrpropagandowymi”6.

Jak z kolei pisano w charakterystyce prymasa Wyszyńskiego, opracowanej przez aparat represji: „Antysocjalistyczna działalność Kościoła zawarta jest w dziewięcioletnim programie tzw. «Wielkiej Nowenny» opracowanym przez Wyszyńskiego. Jest to program katolickiego oddziaływania na społeczeństwo, który ma na celu przeciwdziałanie szerzącej się laicyzacji życia społecznego. Oprócz tego program ten przesiąknięty jest kultem Maryi. Inicjatorem ruchu maryjnego jest Wyszyński” 7 . Sam prymas cele Wielkiej Nowenny ują w następujący sposób: „Wobec totalnego zagrożenia Narodu, będącego pod przemocą Moskwy, wobec ateizacji programowej popieranej przez PZPR, wobec wyniszczenia biologicznego trzeba głębokiego nurtu nadprzyrodzonego, by Naród świadomie czerpał z Kościoła moce boże i umacniał nimi swoje życie religijne i narodowe"s.

${ }_{5}^{5}$ Archiwum Archidiecezjalne Gnieźnieńskie (dalej: AAG), Stefan Wyszyński, Pro Memoria, zapis z 21 XI 1956 r.; Archiwum Archidiecezjalne Warszawskie (dalej: AAW), Sekretariat Prymasa Polski (dalej: SPP), 04/12, Komisja Główna Episkopatu Polski 1957, Protokół Komisji Głównej Episkopatu, Warszawa dn. 20 III 1957 r., k. 1-3. Szerzej zob. R. Łatka, Koniec odwilży w relacjach państwo-Kościót (1957-1958) z perspektywy Prymasa Stefana Wyszyńskiego, w: Christus vincit. Księga dedykowana Biskupowi Edwardowi Frankowskiemu w 80. rocznicę urodzin, red. nauk. M. Krzysztofiński, J. Wołczański, Rzeszów 2017, s. 313-334.

${ }^{6}$ J. Żaryn, „Rok 1966 r. - Obchody milenijne w Kraju i na uchodźstwie”, mps w zbiorach autora, s. 2. Zob. też: Z. Zieliński, Wielka Nowenna na tle powojennych losów Kościoła $w$ Polsce, w: Ecclesia Posnaniensis. Opuscula Mariano Banaszak septuagenario dedicata, Poznań 1998, s. 273-288.

${ }^{7}$ Charakterystyka i ocena działalności społeczno-politycznej kard. Stefana Wyszyńskiego sporządzona przez starszego oficera operacyjnego Wydziału I Departamentu IV MSW Zenona Chmielewskiego, Warszawa 18 XII 1962, w: W stużbie Boga i Polski. Komunistyczna bezpieka wobec kardynała Stefana Wyszyńskiego, red. J. Marecki, F. Musiał, oprac. J. Marecki, P. Nitecki, R. Szczypta-Szczęch, Kraków 2014, s. 163. Por. Tezy, założenia i programy państwowych obchodów Tysiąclecia Państwa Polskiego [i] kościelnych uroczystości Tysiąclecia Chrztu Polski. Pismo dyrektora Departamentu IV MSW S. Morawskiego do Oddziału Prewencji Ogólnej KG MO płk. B. Skulego, 10 XI 1965, Warszawa, w: Obchody milenijne 1966 roku..., s. 19-20; M. Lasota, Donos na Wojtytę. Karol Wojtyła w teczkach bezpieki, Kraków 2006, s. 149-153; E.K. Czaczkowska, Kardynał Wyszyński. Biografia, Kraków 2013, s. 286-287.

${ }^{8}$ S. Wyszyński, op. cit., s. 273. Zob. też: P. Nitecki, Prymas Tysiaclecia, w: W stużbie Boga i Polski..., s. 16-18. 
Prymas Wyszyński w okresie Wielkiej Nowenny posiadał bez wątpienia dominujacca pozycję w Episkopacie Polski. Wiązało się to zarówno z nimbem świętości i poświęcenia, który otaczał go jako więźnia politycznego władz ${ }^{9}$, jak również z mądrą strategią działań, opierająca się na dążeniu do jedności Episkopatu, którą pragnął za wszelką cenę utrzymać. Z tego względu nie rozliczył kreatorów zbyt ugodowej w jego przekonaniu polityki Kościoła w latach 1953-1956 r. - bp. Michała Klepacza i Zygmunta Choromańskiego, a nawet uczynił ich swoimi bliskimi współpracownikami w kolejnych latach. Wykazał się pod tym względem zmysłem realizmu politycznego i pokazał w jednoznaczny sposób, że jedność jest ważniejsza od własnego interesu. Prymas swoje spojrzenie na jedność Episkopatu tłumaczył pod koniec 1965 r. w następujący sposób: „Powziętym większościa głosów na Konferencjach Plenarnych uchwałom muszą podporządkować się Biskupi Diecezjalni, choćby na daną sprawę mieli odrębne spojrzenie. Listy pasterskie uchwalone na Konferencjach Plenarnych nie moga być zmieniane przez poszczególnych Biskupów Diecezjalnych"10. Władze partyjne, a szczególnie Gomułka uważał, że prymas pragnał nie tylko władzy nad Kościołem, ale również chciał sprawować „rząd dusz” w narodzie i z tego powodu intensywnie go zwalczano ${ }^{11}$.

Wojtyła przez większość trwania Wielkiej Nowenny był sufraganem abp. Eugeniusza Baziaka i wikariuszem generalnym metropolii krakowskiej. Jego rola wraz z biegiem czasu systematycznie się zwiększała, gdyż schorowany abp Baziak nie był w stanie sprawować wszystkich obowiązków ordynariusza archidiecezji. Po jego śmierci bp Wojtyła stał się jednym z trzech kandydatów na opuszczone stanowisko metropolity krakowskiego. Władze partyjne oraz UdsW, wyrażając zgodę, by wspomniane stanowisko obją bp Wojtyła, liczyły, że uda się doprowadzić do jego konfliktu z prymasem, który ponoć nie był zadowolony z jego działalności i ledwo ją tolerowa ${ }^{12}$. Ponadto $\mathrm{w}$ dokumentacji

\footnotetext{
9 Jak wspominał bp Ignacy Jeż: „Po wyjściu na wolność Wyszyński był już prymasem nie tylko z nazwy, ale prawdziwym primus inter pares. [...] $\mathrm{Z}$ chwila aresztowania prymasa wszystkie zastrzeżenia, jakie mieliśmy do niego w związku z polityką wobec komunistów, zniknęły. Odtąd widzieliśmy w nim męczennika i bohatera”. E.K. Czaczkowska, op. cit., s. 280.

10 A. Dudek, R. Gryz, op. cit., s. 187-188.

11 E.K. Czaczkowska, op. cit., s. 286-344.

12 A. Dudek, Państwo i Kościót w Polsce 1945-1970, Kraków 1995, s. 169-170. Szerzej zob. G. Ryś, O krakowskie aggiogramento. Archidiecezja krakowska pod rzadami arcybiskupa Wojtyty (1963-1978), w: Kościót krakowski w tysiqcleciu, Kraków 2000, s. 451-481; M. Lasota, Donos na Wojtytę..., s. 106; R. Łatka, Polityka wtadz Polski „ludowej” wobec Kościoła katolickiego w latach 1944-1979 (przypadek krakowski), „Zeszyty Historyczne WiN-u” 2014, nr 39, s. 175-188; E.K. Czaczkowska, op. cit., s. 479-480. W donosie agenturalnym ks. Mieczysława Satory TW ps. Marecki ze stycznia 1964 r. znalazło się nawet stwierdzenie, że bp Wojtyła potrafił otwarcie sprzeciwiać się poleceniom prymasa. Fragment doniesienia spisanego przez funkcjonariusza SB po spotkaniu z TW ps. „Marecki” dotyczący nominacji bp. Karola Wojtyły na arcybiskupa i metropolitę krakowskiego, Kraków 21 I 1964, w: Ku prawdzie i wolności..., s. 200-202.
} 
krakowskiego UdsW zauważano, iż niezadowolenie kard. Wyszyńskiego miały budzić ustępstwa krakowskiego sufragana wobec władz i chęć posiadania samodzielnej pozycji w Episkopacie ${ }^{13}$.

Zarówno jako biskup pomocniczy, jak i arcybiskup metropolita krakowski Wojtyła cele Wielkiej Nowenny i jej zamierzony efekt widział w analogiczny sposób jak kard. Wyszyński. Świadczą o tym jego wypowiedzi, działania, a także analizy sporządzane przez antykościelne struktury Polski „ludowej” ${ }^{14}$. Metropolita krakowski zaznaczał:

Kościół od zarania włączył się w nurt dziejowy narodu i nigdy go nie opuścił. Naród również był zawsze wierny kościołowi [sic!] stąd powiedzenie „Polonia semper fidelis”, że tak było świadkami są św. Wojciech i św. Stanisław. [...] Między kościołem [sic!] a władzą świecką może zajść konflikt, ale tylko wtedy, jeżeli władza świecka nie uznaje wartości duchowych, tak jak to miało miejsce za czasów św. Stanisława. Są sytuacje, że trzeba posłuchać Boga, a nie ludzi. Biskupi muszą mieć odwagę powiedzieć każdemu, „tobie nie godzi się tego uczynić”15.

Również współpracownicy abp. Wojtyły podkreślali po latach, że jeśli chodzi o program Wielkiej Nowenny, między prymasem Wyszyńskim a ówczesnym metropolitą krakowskim nie było zasadniczych różnic ${ }^{16}$.

Niemniej aparat represji cały czas poszukiwał różnic w poglądach bp. Wojtyły i prymasa Polski. Tego typu działania pogłębiły się rzecz jasna po wyborze przyszłego papieża na metropolitę krakowskiego w 1964 r. Tytułem przykładu można przytoczyć raport z donosu ks. Mieczysława Satory z grudnia 1965 r.,

${ }^{13}$ A. Dudek, R. Gryz, op. cit., s. 185; Fragment analizy działalności kard. Stefana Wyszyńskiego w 1964 r. i główne kierunki pracy operacyjnej na 1965 r. sporządzone przez naczelnika Wydziału I Departamentu IV MSW płk. Konrada Straszewskiego, Warszawa 4 III 1964, w: W stużbie Boga i Polski..., s. 319.

${ }^{14}$ Przykładowo w raporcie Służby Bezpieczeństwa (SB) z lipca 1965 r. zauważono, że „Metropolita krakowski w swoich wystapieniach nie negował wprawdzie programu mariologicznego, a nawet oficjalnie uważał za słuszne $\mathrm{w}$ tym względzie postępowanie kard. Wyszyńskiego, niemniej jednak równocześnie akcentował jak ogromne znaczenie dla Polski miał chrzest. Zbyt pochopnym i z gruntu błędnym byłoby jednak twierdzenie, że abp. Wojtyła prowadzi własna, niezależna od Wyszyńskiego politykę. Tak oczywiście nie jest, a przynajmniej oficjalnie metropolita krakowski tego nie wypowiada". Fragment referatu przygotowanego przez funkcjonariuszy Wydziału IV SB KW MO w Krakowie na naradę wydziałowa, dotyczącego działalności abp. Karola Wojtyły, 10 VII 1965, w: Ku prawdzie i wolności..., s. 268. Zob. też: E.K. Czaczkowska, op. cit., s. 299-300.

${ }^{15}$ Cyt. za: AAN, UdsW, 78/83, Działalność duszpasterska, obchody „Millenium”, uroczystości kościelne na terenie miasta Krakowa i województwa, Notatka służbowa z uroczystości na Skałce 8 V 1966, k. 54-55. Por. K. Wojtyła, Kazanie wygłoszone podczas uroczystości Maryi Królowej Polski na Jasnej Górze, 3 V 1966, w: M. Lasota, Wojtyła na podstuchu, Kraków 2014, s. 83-90. Zob. też: J. Żaryn, Dzieje Kościoła..., s. 221.

16 Jak wyjaśniał bp Tadeusz Pieronek: „Bronił prymasa na forum episkopatu. Wygłosił przemówienie, w którym teologicznie uzasadnił akt oddania w niewolę Maryi. Możliwe, że Wojtyła przeprowadziłby go inaczej, ale był przekonany co do samej jego istoty”. Cyt. za: E.K. Czaczkowska, op. cit., s. 299-300. 
w którym akcentował on, że w Rzymie doszło do spięcia między obydwoma hierarchami, wywołanego różnica zdań na temat stosunków państwo-Kościół, oraz orędzia do biskupów niemieckich, „Wojtyła miał rzekomo reprezentować stanowisko, by prowadzić rozmowy z władzami i choć czasem nic to nie da, jednak zawsze jakoś rozmowy przynoszą obustronne korzyści” ${ }^{17}$.

W 1965 r. zdano sobie sprawę, że abp Wojtyła jedynie sprawia wrażenie „biskupa pozytywnego” 18 , równocześnie prowadząc wrogie wobec władz działania, nastawiając duchowieństwo krakowskie w negatywny sposób do struktur państwowych ${ }^{19}$. Najwygodniejszy i najbardziej poręczny pretekst dla władz do ataku na biskupów i próby ich poróżnienia pojawił się w 1965 i był związany z listem biskupów polskich do niemieckich, o czym szerzej w dalszej części analizy.

\section{List do biskupów niemieckich i jego konsekwencje}

Kwestia, która w związku z obchodami milenijnymi wywołała najdalej idące reperkusje ze strony władz, był list biskupów polskich do biskupów niemieckich. To jeden z 56 listów rozesłanych do poszczególnych episkopatów narodowych, ale ze względu na słowa, które w nim padły, i adresata wywołał oburzenie nie tylko zresztą dygnitarzy partyjnych, ale również znaczącej części społeczeństwa mającego w pamięci niemieckie okrucieństwo z czasów II wojny światowej ${ }^{20}$. Stało się tak tym bardziej dlatego, że odpowiedź niemiecka

${ }_{17}$ Doniesienie agenturalne sporządzone przez funkcjonariusza SB po spotkaniu z TW ps. „Marecki” dotyczące wzajemnych relacji pomiędzy kard. Stefanem Wyszyńskim a abp. Karolem Wojtyła, 18 XII 1965 r., w: Ku prawdzie $i$ wolności..., s. 289. Tego typu działania jeszcze rozszerzono po nominacji kardynalskiej Wojtyły. Szerzej zob. E.K. Czaczkowska, op. cit., s. 481-485.

18 Jak podkreślano z kolei w charakterystyce przygotowanej przez UdsW: „Wojtyła opowiada się za normalizacją stosunków pomiędzy Państwem i Kościołem, między PRL a Watykanem. Jednak warunki takiego porozumienia nie powinny w niczym osłabić pozycji i uszczuplić stanu posiadania Kościoła w Polsce. Ten punkt widzenia znalazł swe odbicie m.in. w ocenie porozumienia zawartego między PRL, a Watykanem, które jak to określił były oparte na zasadzie „modus moriendi”. Wojtyła jest zwolennikiem dialogu światopoglądowego, wychodząc przy tym z założenia, że „nie atak frontalny, a sączenie wątpliwości w słuszność marksistowskich tez może zmiękczyć ich stanowisko". AAN, UdsW, 76/5, Działalność ks. Kardynała Wojtyły tom I, Charakterystyka arcybpa. Karola Wojtyły, k. 25.

19 A. Dudek, R. Gryz, op. cit., s. 186. W notatce SB z 21 I 1965 r. podkreślano: „Działalność Wojtyły nie ma wyraźnie politycznie wrogiego charakteru, to jednak ideologicznie jest bardzo szkodliwa, szczególnie na odcinku intelektualistów i inteligencji”. Notatka dotycząca starań abp. Wojtyły o otrzymanie paszportu, Warszawa 21 I 1965, w: Ku prawdzie i wolności..., s. 235.

${ }^{20} \mathrm{Na}$ ten temat szerzej zob. P. Madajczyk, „Przebaczamy i prosimy o przebaczenie...”, „Więź” 1990, nr 9; idem, Na drodze do pojednania. Wokót orędzia biskupów polskich do biskupów niemieckich z 1965 roku, Warszawa 1994; W. Janowski, Orędzie biskupów polskich do 
była dość wstrzemięźliwa i z pewnością rozczarowująca dla polskich biskupów. Pisał o tym wprost prymas Wyszyński w swoim liście do kard. Juliusa Dopfnera z 1970 r.: „Muszę wszakże księdzu Kardynałowi szczerze wyznać, że odpowiedź Episkopatu niemieckiego, na nasz pojednawczy list (z 1965 r.) rozczarowała nie tylko Polaków, ale i światową opinię publiczną. Naszą tak serdecznie wyciagniętą rękę przyjęto nie bez zastrzeżeń" ${ }^{21}$.

Akcja propagandowa, przygotowana przez dygnitarzy partyjnych, wymierzona została w Episkopat i personalnie w prymasa Wyszyńskiego, abp. Bolesława Kominka i abp. Wojtyłę, którzy brali udział w pracach nad listem ${ }^{22}$. Poza intensywnymi atakami prasy władze postanowiły nie wydawać prymasowi paszportu na wyjazd do Rzymu ${ }^{23}$. Stanowisko PZPR przedstawił osobiście Gomułka, który w czasie przemówienia wygłoszonego na forum Ogólnopolskiego Komitetu Frontu Jedności Narodu z 14 I 1966 r. powiedział:

Sprawa polega na tym, że episkopat, a szczególnie kardynał Wyszyński chce przeciwstawić 1000-lecie chrztu Polsce Ludowej. Tendencja ta przebija z całego orędzia. [...] Dlatego właśnie odmówiliśmy kardynałowi Wyszyńskiemu paszportu, ażeby nie spotkał się ze swoim nauczycielem prof. Haleckim, którego cytuje, ażeby nie mógł

biskupów niemieckich i obchody Tysiaclecia Chrztu Polski Państwowości Polskiej na tle stosunków państwo-Kościót - w opiniach i komentarzach zachodnich środków masowego przekazu, w: Millennium polskie..., s. 121-149; A. Chmiel, Prasa krajów socjalistycznych o Orędziu biskupów polskich do biskupów niemieckich i obchodach Millenium, w: Millennium polskie..., s. 150-166; J. Żaryn, Dzieje Kościoła..., s. 234-241; S. Stępień, Sobór Watykański II i orędzie Episkopatu Polski do biskupów niemieckich, w: Milenium czy Tysiaclecie..., s. 44-51. Głównym inicjatorem listu był bp Kominek. Szerzej zob. Wokót orędzia. Kardynat Bolestaw Kominek prekursor pojednania polsko-niemieckiego, red. W. Kucharski, G. Strauchold, Wrocław 2009; T. Krawczak, Orędzie biskupów polskich w ocenie struktur partyjnych i Stużby Bezpieczeństwa, w: Pojednanie i polityka. Polsko-niemieckie inicjatywy pojednania $w$ latach sześćdziesiatych XX wieku a polityka odprężenia, red. F. Boll, W.J. Wysocki, K. Zimmer, Warszawa 2010, s. 152-157; P. Nitecki, op. cit., s. 17-18; E.K. Czaczkowska, op. cit., s. 538-567.

${ }^{21}$ Cyt. za: A. Dudek, R. Gryz, op. cit., s. 220-221. Zob. też: E.K. Czaczkowska, op. cit., s. 538, $559-560$.

22 A. Dudek, R. Gryz, op. cit., s. 218. Ponadto niewydanie paszportu prymasowi miało w optyce aparatu represji przyczynić się do pogłębienia „sprzeczności w Episkopacie” oraz ośmielić nieprzychylnie do niego nastawionych biskupów. Notatka dotycząca wydania paszportu kard. Stefanowi Wyszyńskiemu, sporządzona przez funkcjonariuszy MSW, Warszawa 17 VIII 1965, w: W stużbie Boga i Polski..., s. 337; Wniosek o wstrzymanie paszportów dla kard. Stefana Wyszyńskiego i innych hierarchów biorących udział w opracowaniu orędzia biskupów polskich do biskupów niemieckich, Warszawa 23 XII 1965 r., w: W stużbie Boga i Polski..., s. 358-360.

${ }^{23}$ P. Raina, Kardynał Wyszyński..., s. 9-14. Jak odnotował prymas: „Bp. Z. Choromanski jest zdania, że Prymasowi nie wypada się odwoływać od takich decyzji. Uważa, że ta odmowa będzie na chwałę Kościoła. Proszę by biskup na razie odpowiedział i zaprotestował przeciwko jednostronnemu werdyktowi, przesądzającemu o winie Prymasa Polski, z wymiarem kary”. Zapis z 7 I 1966. Bp Choromański 10 stycznia skierował w tej sprawie pismo do szefa Urzędu Rady Ministrów Janusza Wieczorka. Treść pisma: ibidem, s. 11. 
przeciwstawić 1000-lecia państwa polskiego 1000-leciu wkroczenia chrześcijaństwa na ziemię polska. [...] niech kościół [sic!] nie przeciwstawia się państwu. Niech nie uważa, że sprawuję rząd dusz w narodzie. Czasy te odeszły w bezpowrotną przeszłość i nigdy już nie powrócą ${ }^{24}$.

Prymas skutek wspomnianych działań władz oceniał jako korzystny dla Kościoła:

Można natomiast zastanowić się nad rezultatami tej całej akcji, tego tryptyku działań: orędzie, paszport, mowa Władysława Gomułki. Rezultaty oczywiście jeszcze trudno jest $\mathrm{w}$ tej chwili oceniać, bo nie mamy wszystkich elementów, zebranych z kraju i zagranicy. Gdy idzie o rezultaty w Polsce, wydaje mi się, że raczej są dodatnie, pomimo, że w niektórych kołach, zwłaszcza inteligenckich, jakiś osad niewątpliwie pozostał. Jednak wydaje mi się, że cała ta akcja uwydatniła w jakimś mierze wrażliwość społeczeństwa polskiego na Millenium. Co więcej, ma to nawet znaczenie polityczne dla partii, która przypomniała sobie Millenium i zaczęła na gwałt znowu o nim mówić, oczywiście po swojemu, jak zawsze dotychczas ${ }^{25}$.

Specjalnym działaniem krakowskich władz było zainspirowanie pracowników Krakowskich Zakładów Sodowych „Solvay” do opublikowania listu do metropolity, w którym oskarżano go o przekroczenie kompetencji i wypowiadanie się w „imieniu władzy ludowej”26. Na list odpowiedział osobiście abp Wojtyła, który poczuł się nim mocno dotknięty, ponieważ pracował w czasie wojny w Zakładach „Solvay”. Tłumaczył, że oskarżenia wynikały z niedoinformowania co do treści i motywacji biskupów. List abp. Wojtyły odczytano w kościołach archidiecezji krakowskiej. Atak propagandowy okazał się, jak pisze wielu autorów, dość skuteczny, a przede wszystkim bolesny dla adresata ${ }^{27}$.

${ }^{24}$ Cyt. za: A. Dudek, R. Gryz, op. cit., s. 229. Zob. też: P. Raina, Kardynał Wyszyński..., s. 12.

25 S. Wyszyński, „Sprawy gorące” Kościoła Millenijnego w Polsce. Przemówienie do księży dziekanów archidiecezji gnieźnieńskiej, Gniezno 3 II 1966, w: P. Raina, Kardynał Wyszyński..., s. 19. Analogiczne oceniali sytuację członkowie Komisji Głównej Episkopatu: „Wszyscy członkowie Komisji Głównej stwierdzaja, że był to fałszywy krok Władz [sic!] państwowych spowodował wrzawę na całym świecie, odwrócił uwagę zacietrzewionych od Orędzia, a wzbudził sympatię do Prymasa Polski i w rezultacie pomógł Kościołowi”. AAW, SPP, 04/21, Komisja Główna Episkopatu Polski 1966 r., Protokół Komisji Głównej Episkopatu Polski z 17 I 1966, k. 17.

${ }^{26}$ Treść listu: Teczki Wojtyły, Kraków 2003, s. 92-93. Jak zauważył bp Julian Groblicki w czasie spotkania opłatkowego dla księży archidiecezji krakowskiej: „[...] dziś rano $\mathrm{z}$ "Solvayu» zgłosili się do kurii robotnicy, twierdząc, że nie wiedza, kiedy w ich imieniu napisany został list, po czym dodał, że praktyka opracowywania «wypowiedzi» do prasy w imieniu szkół i załóg jest częsta”. Notatka sporządzona przez funkcjonariusza SB po spotkaniu z TW ps. „Parys” dotycząca orędzia biskupów polskich do biskupów niemieckich, 22 XII 1965, w: Ku prawdzie i wolności..., s. 294.

${ }_{27}$ J. Kracik, Krakowskie Millenium, w: Karol Wojtyła jako biskup krakowski, red. T. Pieronek, R.M. Zawadzki, Kraków 1998, s. 251-252; M. Lasota, Działania operacyjne UB-SB przeciwko kard. Karolowi Wojtyle, w: Ku prawdzie i wolności..., s. 22; idem, Donos na Wojtytę..., s. 145-149; R. Łatka, Polityka władz PRL wobec Kościoła katolickiego w województwie krakowskim w latach 1980-1989, Kraków 2016, s. 74. 
Metropolita krakowski zauważył, iż wspomniany list miał ścisły związek z kościelnymi przygotowaniami do obchodów millennium chrztu Polski ${ }^{28}$.

Działania władz wobec abp. Wojtyły wpisywały się w szerszy plan związany z chęcia doprowadzenia do wywołania konfliktu i różnicy zdań w Episkopacie na tle listu do biskupów niemieckich. Z tego względu władze wojewódzkie przeprowadziły szereg rozmów z ordynariuszami diecezji i ich sufraganami, dążąc do tego, by część biskupów odcięła się od inicjatywy Episkopatu. Wspomniane działania przyniosły pewien skutek, gdyż niewielka część biskupów zajęła negatywne stanowisko co do listu do biskupów niemieckich ${ }^{29}$, a kilku kolejnych zachowało wstrzemięźliwość co do okazywania poparcia dla tej inicjatywy ${ }^{30}$. Wśród tych drugich znalazł się abp Wojtyła, który bronił koncepcji listu, ale jednocześnie dystansował się od sugestii władz, że był jednym z jego autorów $^{31}$. Wydaje się, że tego typu postawa została obliczona na niewywoływanie otwartego konfliktu z władzami.

Taka interpretacja jest tym bardziej prawdopodobna, że abp Wojtyła na początku $1966 \mathrm{r}$. wysłał do prymasa list, w którym jednoznacznie solidaryzował się z nim w kwestii ataków propagandowych związanych z listem do biskupów niemieckich oraz odmowy wydania paszportu na wyjazd do Rzymu na inaugurację uroczystości milenijnych $\mathrm{w}$ Kościele powszechnym ${ }^{32}$. Była to również odpowiedź na Komunikat Urzędu Rady Ministrów, w którym władze zajęły agresywne stanowisko wobec listu. Metropolita krakowski zauważył w nim, że biskupom w propagandowy sposób insynuuje się czyny i motywy, ,jakie nie miały miejsca" oraz wpisuje się w założenia zachodnioniemieckiej prasy rewizjonistycznej, sugerujacc, że biskupi nie zajęli zdecydowanego stanowiska w kwestii zachodniej granicy. Wojtyła odrzucał taką argumentację, podkreślając, że list do biskupów niemieckich „służy [...] najlepiej sprawą naszej Ojczyzny, że stawia ją w moralnej awangardzie współczesnej ludzkości, a zarazem nawiązuje do tego, co stanowiło prawdziwe morale naszych dziejów. Jesteśmy natomiast przekonani, że wypaczenie właściwego charakteru listu do Biskupów niemieckich, oraz cała tendencyjna jego interpretacja, jaką od rewizjonistycznej niemieckiej prasy przejęła prasa [...] istotnie szkodzi słusznej sprawie naszej Ojczyzny" ${ }^{33}$.

${ }^{28}$ M. Lasota, Donos na Wojtytę..., s. 149.

${ }^{29}$ Otwarcie od treści listu zdystansował się bp Edmund Nowicki, ordynariusz gdański. Na ten temat szerzej zob. D. Gucewicz, op. cit., s. 137-148.

30 A. Dudek, R. Gryz, op. cit., s. 230-231.

${ }^{31}$ P. Madajczyk, Na drodze do pojednania..., s. 145; A. Dudek, R. Gryz, op. cit., s. 230-231.

32 Jak zauważono z kolei w notatce funkcjonariusza SB po spotkaniu z ks. Konstantym Krzywnankiem TW ps. Parys, abp Wojtyła całą propagandową nagonkę władz określił jako zniesławienie, podczas gdy list do biskupów niemieckich miał ogromne międzynarodowe znaczenie dla Polski. Notatka sporządzona przez funkcjonariusza SB po spotkaniu z TW ps. „Parys” dotycząca orędzia biskupów polskich do biskupów niemieckich, 22 XII 1965, w: Ku prawdzie i wolności..., s. 292.

${ }^{33}$ AAW, SPP, Rada Główna Episkopatu Polski 1966 r., List abp. Karola Wojtyły metropolity krakowskiego do Prymasa Polski kard. Stefana Wyszyńskiego, 11 I 1966, k. 2-3. Analogiczne 
Należy podkreślić, że analogiczne stanowisko w kwestii listu do biskupów niemieckich zają dokładnie w tym samym czasie prymas, który jego znaczenie określił w kazaniu wygłoszonym 13 I 1966 r.: „To orędzie, może tu, w kraju wywołało pewne zamieszanie, zwłaszcza wśród inteligencji, ale w wymiarze światowym jeszcze bardziej podniosło pozycję Kościoła polskiego, poprawiło sądy o tym Kościele i sprawiło, że w obliczu takiego dokumentu wszystkie zarzuty o szowinizm, nacjonalizm od razu umarły"34.

Wojtyła w dalszej części listu pisał w imieniu swoim i biskupów krakowskich:

Odmowa paszportu nieodzownego dla Waszej Eminencji, aby mógł zainicjować w Rzymie przy obecności Ojca Św. Millenium Chrztu Polski nie może być inaczej rozumiana jak tylko jako przejaw dążności do paraliżowania uroczystości millenijnych. Uzasadnienie tej odmowy dokonane w sposób taki, jak w Komunikacie, nie może przesłonić owej dążności. Pragnę przekazać Waszej Eminencji wyrazy biskupiej solidarności. Komunikat URM godzi wszak w cały Episkopat Polski. Do tych wyrazów dołączam moje oraz moich Braci Biskupów w Krakowie głębokie homagium. Płynie ono w bieżących okolicznościach z najgruntowniejszego przekonania, iż te szczególne ofiary, jakie Wasza Eminencja ponosi w szczególny też sposób służą sprawie Bożej w naszej Ojczyźnie, a także w całym Kościele i świecie współczesnym ${ }^{35}$.

Analogiczne stanowisko zajęli pozostali biskupi, którzy skierowali w marcu 1966 r. pismo stanowiące „wyraz braterskiej solidarności z X. Prymasem, z Jego postawa pasterską i zaprotestowali przeciwko atakom prasowym niesprawiedliwie krzywdzącym osobę X. Kardynała Prymasa" ${ }^{36}$.

Władze mimo jednoznacznej postawy biskupów, którzy stanęli solidarnie po stronie prymasa, zdecydowały, iż nie wydadzą mu paszportu nie tylko na wyjazd do Rzymu, ale również na uroczystości w Wielkiej Brytanii, Stanach Zjednoczonych i Kanadzie. Wyrażały za to zgodę na wyjazd na uroczystości organizowane przez Polonię innego ordynariusza, delegowanego przez episkopat ${ }^{37}$. Biskupi nie podjęli jednak „gry” władz, która była obliczona

stanowisko abp Wojtyła zajął w piśmie Episkopatu Polski do premiera Józefa Cyrankiewicza, którego był głównym autorem. List Episkopatu Polski do prezesa Rady Ministrów Józefa Cyrankiewicza z 10 II 1966, w: P. Raina, Kardynat Wyszyński..., s. 28-33. Wojtyła potwierdził swoje spostrzeżenia również w czasie posiedzenia Komisji Głównej Episkopatu 17 I 1966, gdy zauważył, że „nikt myślący nie posądza biskupów o propagowaną zdradę stanu, chociaż ludzie którzy ubolewają nad złośliwością i przewrotnością propagandy uważaja, że niektóre sformułowania Orędzia nie zostały wyważone i obliczone na ewentualna reakcje społeczeństwa”. AAW, SPP, 04/21, Komisja Główna Episkopatu Polski 1966 r., Protokół Komisji Głównej Episkopatu Polski z 17 I 1966, k. 16.

${ }^{34}$ P. Madajczyk, Na drodze do pojednania..., s. 226.

35 AAW, SPP, Rada Główna Episkopatu Polski 1966 r., List abp. Karola Wojtyły metropolity krakowskiego do Prymasa Polski kard. Stefana Wyszyńskiego, 11 I 1966, k. 4.

${ }^{36}$ A. Dudek, R. Gryz, op. cit., s. 231

${ }^{37}$ Pismo dyrektora Urzędu ds. Wyznań Aleksandra Skarżyńskiego do sekretarza Episkopatu Polski bp. Zygmunta Choromańskiego w sprawie wydania prymasowi paszportu na wyjazd za granicę, Warszawa 11 VI 1966, w: P. Raina, Kardynat Wyszyński..., s. 83. 
na skłócenie episkopatu i zajęli konsekwentne stanowisko, iż tylko prymas może reprezentować polski Kościół. Ponownie pusty tron kard. Wyszyńskiego stał się wymownym znakiem antykościelnej polityki władz PRL już nie tylko wewnątrz kraju, ale również w całym świecie chrześcijańskim ${ }^{38}$.

Wspomniane wyżej działania wymierzone były w jedność episkopatu i pozycje prymasa Wyszyńskiego, który dbał o to, by biskupi zajmowali jednolite stanowisko. Mimo że udało się doprowadzić do różnicy zdań w łonie episkopatu, to władzom nie powiódł się szerszy plan mający na celu podważenie pozycji prymasa i pokazanie biskupów jako sojuszników „niemieckich rewanżystów”. Jak trafnie zauważył Jan Żaryn: „Treść Orędzia na moment oddaliła wiernych od pryncypialnego prymasa interrexa, za to represje zastosowane wobec kardynała ponownie ich do niego zbliżyły"39.

W obecnej chwili wśród badaczy dziejów najnowszych nie ma również wątpliwości, iż to właśnie ta inicjatywa prymasa Wyszyńskiego i polskiego episkopatu rozpoczęła proces pojednania polsko-niemieckiego ${ }^{40}$.

\section{Kard. Wyszyński i abp Wojtyła w roku milenijnym}

Rok 1966 upływał pod znakiem intensywnych działań władz, które zmierzały w dwóch zasadniczych kierunkach: marginalizacji i stwarzaniu utrudnień dla obchodów kościelnych oraz organizacji konkurencyjnych uroczystości mających przyćmić obchody przygotowane przez Episkopat Polski ${ }^{41}$. Było to widoczne w czasie uroczystości zaplanowanych w każdym regionie kraju. Zgodnie z wytycznymi formułowanymi przez dygnitarzy partyjnych należało przeciwstawiać się „ofensywie klerykalizmu”, która miała na celu „sfanatyzowanie religijne społeczeństwa" ${ }^{42}$. Starano się również sprowokować biskupów do ostrych odpowiedzi przez organizowanie rozmaitych prowokacji. Jak zauważył prymas, co odnotowała kielecka bezpieka: „Władzom taka sytuacja

38 Szerzej zob. Obchody Millenium...

39 J. Żaryn, Dzieje Kościoła..., s. 240.

${ }^{40}$ Ł. Marek, „Kler to nasz wróg”. Polityka wtadz państwowych wobec Kościoła katolickiego na terenie województwa katowickiego w latach 1956-1970, Katowice 2009, s. 221-229; Pojednanie i polityka...

${ }^{41}$ P. Raina, Kardynat Wyszyński..., s. 91-139; J. Żaryn, Dzieje Kościoła..., s. 242-250; E.K. Czaczkowska, op. cit., s. 300-303.

42 Tezy, założenia i programy państwowych obchodów Tysiąclecia Państwa Polskiego [i] kościelnych uroczystości Tysiąclecia Chrztu Polski. Pismo dyrektora Departamentu IV MSW S. Morawskiego do Oddziału Prewencji Ogólnej KG MO płk. B. Skulego, 10 XI 1965, Warszawa, w: Obchody milenijne 1966 roku..., s. 19-20. Zob. M. Lasota, Donos na Wojtytę..., s. 149-153. Episkopat zgodnie ze wskazaniami Komisji Głównej zachowywał „spokój i umiar” oraz miał nadawać uroczystościom „modlitewno-dziękczynny charakter”. AAW, SPP, 04/21, Komisja Główna Episkopatu Polski 1966 r., Protokół Komisji Głównej Episkopatu Polski z 8 V 1966, k. 54. 
potrzebna jest po to, aby móc generalnie uderzyć w kościół [sic!] i zabronić obchodów millenijnych [...] Wyszyński wyciagnął z tego następujące wnioski: nie wolno dać się sprowokować, kazania głosić uspokajające, co pozwoli zrealizować do końca program millenijnych uroczystości. Wyszyński ocenił też, że postawa biskupów na tle polityki władz powoduje skupienie się ludzi wokół kościoła [sic!]”43.

To właśnie na kard. Wyszyńskim skupiała się optyka władz - w tym okresie oceniano go jako nieprzejednanego przeciwnika odpowiedzialnego za dążenie w kierunku „klerykalizacji” życia publicznego. Prymas był atakowany propagandowo w bezwzględny sposób w prasie i przemówieniach poszczególnych dygnitarzy partyjnych. Najostrzejszy atak na kard. Wyszyńskiego przeprowadził 17 kwietnia w Poznaniu Gomułka, oskarżając prymasa o wyzbycie się poczucia państwowości oraz nieodpowiedzialność: „Ten wojujacy z naszym państwem ludowym pasterz pasterzy, który głosi, że nie będzie się korzył przed polska racja stanu, stawia swoje urojone pretensje do duchowego zwierzchnictwa nad narodem polskim wyżej niż niepodległość Polski. Jakież to musi być zaślepienie, które każe mu zapomnieć o naukach historii, zapomnieć o tym, kto Polskę zgubił, a kto ją wyzwolił"44.

Centralne uroczystości milenijne odbyły się 3 maja na Jasnej Górze. Prymas wobec decyzji władz o niewpuszczeniu Pawła VI do kraju pełnił w ich czasie funkcję legata papieskiego, zastępując nieobecnego Ojca Świętego. Jak podkreślał prymas Wyszyński w czasie obrad Rady Głównej Episkopatu Polski: „Nie pozwolono Ojcu Świętemu przybyć do Częstochowy w charakterze pielgrzyma. Odmówienie papieżowi wjazdu do Polski jest zniewaga wyrządzaną Ochrzczonemu Narodowi Polskiemu, a nawet całemu Kościołowi Powszechnemu"45. Już ta część obchodów pokazywała siłę polskiego Kościoła, gdyż w uroczystościach, mimo stwarzania przez władze rozmaitych trudności, wzięło udział co najmniej 300 tys. wiernych ${ }^{46}$.

Władze zdawały sobie sprawę, że jednym z najważniejszych punktów obchodów milenijnych będzie Kraków: „Szczególną rolę w obchodach tysiąclecia chrztu Polski według założeń Episkopatu ma odegrać kuria krakowska.

\footnotetext{
${ }^{43}$ J. Żaryn, Dzieje Kościoła..., s. 247. Analogiczne stanowisko wyraził prymas w swoich zapiskach: „Choćby wypowiedziano "wojnę», nie będę się uważał za stronę wojująca, bo ja wojny nie prowadzę. Jestem tylko obwiniany, gdy prasa «usilnie oskarż» mnie o wszystkie zbrodnie. Ufam, że katolicy nie dadzą się sprowokować. Proszę nosicieli wieści, by zachowali spokój i ufność ku Bogu”. Cyt. za: P. Raina, Kardynat Wyszyński..., s. 79. Zob. też: S. Wyszyński, op. cit., s. 71.

${ }^{44}$ A. Dudek, R. Gryz, op. cit., s. 237. Zob. też: E.K. Czaczkowska, op. cit., s. 389-390.

${ }^{45}$ Cyt. za: J. Żaryn, Millennium w pętli komunizmu, „W Sieci Historii” 2016, nr 4, s. 23. Zob. też: A. Dudek, R. Gryz, op. cit., s. 238. Analogiczne stanowisko zajęła Komisja Główna Episkopatu. AAW, SPP, 04/21, Komisja Główna Episkopatu Polski 1966 r., Protokół Komisji Głównej Episkopatu Polski z 8 V 1966, k. 53.
}

${ }^{46}$ J. Żaryn, Dzieje Kościoła..., s. 251-252. 
Wiąże się to z historycznym znaczeniem Krakowa i metropolii krakowskiej, posiadającej wg opinii duchowieństwa szczególny dorobek w dziejach polskiego Kościoła” ${ }^{47}$. Wynikało to z faktu, iż zgodnie z planem przygotowanym przez prymasa Wyszyńskiego uroczystości w archidiecezji krakowskiej winny mieć najwyższa po obchodach $\mathrm{w}$ Częstochowie rangę. Uczestniczyli w nich członkowie Episkopatu, którzy odbyli, podobnie jak w kilku innych miastach Polski, specjalną sesję Konferencji Episkopatu ${ }^{48}$.

Z tego względu do kontroli uroczystości milenijnych w Krakowie i przygotowania konkurencyjnych obchodów zmobilizowano znaczące siły aparatu represji i Milicji Obywatelskiej ${ }^{49}$. Poza zaangażowaniem wielu środków materialnych władze wojewódzkie wywierały systematyczne naciski na abp. Wojtyłę, zmierzające do ograniczenia zasięgu uroczystości kościelnych. Władze wojewódzkie bez konsultacji z kurią krakowską 6 maja dokonały zmiany trasy przejazdu obrazu Matki Boskiej Częstochowskiej do Krakowa, którego przywitanie było integralnym elementem obchodów. Spotkało się to z protestem zarówno metropolity krakowskiego ${ }^{50}$, jak i apelem kard. Wyszyńskiego, który w czasie nabożeństwa 7 maja w kościele Mariackim „zaapelował do zebranych aby wczorajsze smutne wydarzenia /zmiana trasy/ poszło $\mathrm{w}$ niepamięć i aby wyjść w niedziele z procesji z pogodą ducha, a próbę czynienia przeszkód określił jako dziecinadę" ${ }^{" 1}$.

${ }^{47}$ Cyt. za: M. Lasota, Donos na Wojtyłę..., s. 152. Por. Pismo kierownika Wydziału Administracyjnego KW PZPR w Krakowie Eugeniusza Pieczki do Wydziału Administracyjnego KC PZPR oceniające uroczystości Kościoła krakowskiego w dniach 2-8 maja 1966 r., 21 V 1966, w: Teczki Wojtyty..., s. 116; P. Natanek, Obchody millenium w archidiecezji krakowskiej, w: Studia i rozprawy ofiarowane profesorowi Tytusowi Górskiemu, Kraków 2003, s. 151-152; J. Kracik, op. cit., s. 249-257.

${ }^{48}$ AAN, UdsW, 78/83, Działalność duszpasterska, obchody „Millenium”, uroczystości kościelne na terenie miasta Krakowa i województwa, Ocena uroczystości kościelnych w Krakowie w dniach 6-8 maja 1966 r., k. 59; P. Raina, „Te Deum”..., s. 172-174; M. Lasota, Od Karola Wojtyty do Jana Pawła II Wielkiego, w: Ku prawdzie i wolności..., s. 11.

${ }^{49}$ M. Lasota, Małopolska, w: Milenium czy Tysiqclecie..., s. 196-202; M. Komaniecka, Inwigilacja Kościoła katolickiego przez SB podczas obchodów millenijnych w 1966 roku $w$ Krakowie, ze szczególnym uwzględnieniem działalności Wydziałów pomocniczych „B”, „T”, „W”, w: Kościót katolicki w czasie komunistycznej dyktatury. Między bohaterstwem a agentura, t. II, red. R. Terlecki, J. Szczepaniak, Kraków 2008, s. 110; F. Musiał, „Do wspótpracy z nami dobierać..." Pierwsze lata działalności Wydziału IV SB KW MO w Krakowie, w: idem, Raj grabarzy Narodu. Studia i materiaty do dziejów aparatu represji w Polsce „ludowej” 1945-1989, Kraków 2010, s. 239.

${ }^{50}$ Wojtyła wysłał do przewodniczącego Rady Miasta Krakowa ostry telegram, w którym protestował przeciwko zmianie trasy. AAN, UdsW, 78/83, Działalność duszpasterska, obchody „Millenium”, uroczystości kościelne na terenie miasta Krakowa i województwa, Odpis telegramu nadanego w dniu 7 maja przez abp. Wojtyłę do Przewodniczącego Prezydium RN m. Krakowa /nadany o godz. 9.30 odebrany o 11.30/, k. 66.

${ }^{51}$ Ibidem, Działalność duszpasterska, obchody „Millenium”, uroczystości kościelne na terenie miasta Krakowa i województwa, Uzupełnienie do informacji z 7 maja przekazane w dniu 8 maja przez tow. Tokarskiego o godz. 12.00, k. 39 . 
Krakowskie władze zadały sobie wiele trudu, żeby odciagnąć mieszkańców miasta od obchodów kościelnych. Kluczowe pod tym względem znaczenie miał m.in. mecz Wisła - MTK Budapeszt, na który co prawda przybyło 15 tys. widzów, jednakże 5 tys. osób, które wykupiły bilety, nie znalazło się na stadionie, gdyż „zrezygnowali w ostatniej chwili, udając się na uroczystości kościelne" ${ }^{52}$. Tego typu działania wpisywały się w szerszy plan przygotowany przez władze w każdym regionie kraju. W czasie uroczystości w Krakowie jednakże po raz pierwszy doszło do użycia przemocy ${ }^{53}$.

Krakowskie uroczystości zakończyły się sukcesem, a jak zauważono w dokumentacji UdsW: „w takich inteligenckich ośrodkach jak Kraków i Poznań, gdzie przeprowadziliśmy znaczną akcję krytyki orędzia, Wyszyński i episkopat spotkali się z manifestacyjnym przyjęciem. Fakty te posłużą niewątpliwie Wyszyńskiemu do umocnienia swojej pozycji w kościele [sic!] polskim"54.

W dokumentacji aparatu represji znalazł się również interesujący donos agenturalny, w którym ks. Satora podkreślał, iż władze nie wykorzystały szansy do poróżnienia kard. Wyszyńskiego i abp. Wojtyły. W jego przekonaniu należało podjąć decyzję o transmisji krakowskich obchodów, opatrzona odpowiednim komentarzem, która osłabiałaby frekwencję w ich trakcie. Tego typu decyzja władz mogła wpłynąć na „pogłębianie konfliktu w Episkopacie”, gdyż prymas Wyszyński przekonałby się, że władze idą na rękę abp. Wojtyle, a wielu biskupów sądziłoby, że nie chcą one „robić trudności” metropolicie krakowskiemu ${ }^{55}$.

Kościół poza głównymi uroczystościami z udziałem Episkopatu Polski zaplanował peregrynacje obrazu Matki Boskiej Częstochowskiej, który miał nawiedzić każdą diecezję ${ }^{56}$. Wobec „aresztowania” go przez władze stało się to niemożliwie. Zamiast tego po całej Polsce pielgrzymowały puste ramy obrazu, które wymownie pokazywały, że Polska „ludowa” nie ma nic wspólnego z tolerancją religijną. Biskupi zajęli w tej sprawie zdecydowane stanowisko, wysyłając ostry list skierowany do Rady Państwa, w którym podkreślano:

52 A. Dudek, R. Gryz, op. cit., s. 239-240. Szerzej zob. P. Raina, „Te Deum”..., s. 176.

${ }^{53} \mathrm{Na}$ ten temat szerzej zob. R. Łatka, Rywalizacja państwo-Kościót w czasie obchodów millenijnych na przyktadzie województwa krakowskiego, w: Pót wieku Milenium..., s. 679-705.

${ }^{54}$ A. Dudek, R. Gryz, op. cit., s. 239.

${ }^{55}$ Fragment doniesienia sporządzonego przez funkcjonariusza SB po spotkaniu z TW ps. „Marecki” dotyczącego uroczystości millenijnych w Krakowie i propozycji osłabienia frekwencji podczas uroczystości ku czci św. Stanisława i procesji na Skałkę, $12 \mathrm{~V}$ 1966, Kraków, w: Ku wolności i prawdzie..., s. 299-300. Na temat ks. Satory szerzej zob. J. Szczepaniak, „Wierny” az do śmierci. Tajemna historia ks. Mieczystawa Satory, w: Kościót katolicki w czasach komunistycznej dyktatury. Między bohaterstwem a agentura. Studia i materiały, t. I, red. J. Szczepaniak, R. Terlecki, Kraków 2007, s. 79-134. Zob. też: M. Lasota, Działania aparatu PRL wobec kard. Karola Wojtyty..., s. 24-26.

56 A. Dudek, R. Gryz, op. cit., s. 241-242. 
Odebranie tego Obrazu dokonane siła, a wraz z tym udaremnienie jego funkcji religijnej jest wtargnięciem $\mathrm{w}$ dziedzinę czysto religijna przy użyciu przemocy fizycznej, a równocześnie stanowi wyraźne pogwałcenie uczuć religijnych, oraz ich bolesna obrazę. Obraza ta jest tak oczywista, że nie potrzeba jej ani osobno wyjaśniać ani też udowadniać. Wszelkie zaś próby nadawania kultu religijnemu oraz pracy duszpasterskiej związanej z nawiedzeniem Obrazu Matki Boskiej Częstochowskiej jakiegoś znaczenia politycznego są dalszą tylko jeszcze postacią deprecjonowania religii oraz uczuć religijnych przez odbieranie im właściwego znaczenia. Jest to próba stanowienia o religii z pozycji anty-religijnych, w czym zawiera się oczywiste naruszenie zasady wolności religii i sumienia ${ }^{57}$.

Podsumowując efekty obchodów kościelnych, zauważono w dokumentacji władz na poziomie centralnym: „Pomijając cała stronę dewocyjno-maryjna, faktem jest, że hasła millenijne zwłaszcza dotyczące zagadnień etycznych i społecznych, znalazły dość poważnych oddźwięk w wierzącej części społeczeństwa [...]. Uroczystości millenijne pokazały z całą oczywistościa, że jakiekolwiek administracyjnego ograniczania kościoła palą na panewce. Co więcej stają się niejednokrotnie pośrednim bodźcem do wzmożenia religijności” ${ }^{58}$. Władze miały ponadto świadomość, że dzięki przebiegowi uroczystości milenijnych „Wyszyński wzmocnił swoją pozycję w episkopacie i wśród kleru, a wobec Watykanu i Rządu [sic!] zademonstrował swoją siłę i jeszcze mocniejsze wpływy"59. Prymas Wyszyński w czasie posiedzenia Komisji Głównej z 30 VIII 1966 r. stwierdził jednoznacznie: „kościelne uroczystości millenijne wypadły lepiej niż się spodziewaliśmy. Biskupi Ordynariusze zyskuja na znaczeniu"60.

${ }^{57}$ List Episkopatu Polski do Rady Państwa protestujacy przeciwko pogwałceniu uczuć wierzacych, Warszawa 21 XI 1966, w: P. Raina, Kardynat Wyszyński..., s. 218. Jak tłumaczył bp Ignacy Jeż: „Komuniści się bali, że ten obraz ich zniszczy. Byli słabi”. Cyt. za: E.K. Czaczkowska, op. cit., s. 398.

${ }^{58}$ Cyt. za: A. Dudek, R. Gryz, op. cit., s. 244. Warto w tym miejscu dodać, że w dokumentacji władz centralnych nie było zgodności co do oceny przebiegu uroczystości kościelnych i efektów, jakie one moga przynieść. Przykładowo w opracowaniu UdsW prawdopodobnie z maja 1966 r. podkreślano, że „Przebieg uroczystości kościelnych, szczególnie w Częstochowie, utwierdził opinię naszego kraju i świata, że w Polsce lud wierzący jest daleki od popierania antynarodowej polityki episkopatu i Wyszyńskiego w szczególności”. Opracowanie Urzędu ds. Wyznań: Ocena przebiegu centralnych uroczystości kościelnych w okresie od 14 kwietnia do 8 maja 1966 r., w: P. Raina, Kardynat Wyszyński..., s. 252.

59 AAN, UdsW, 78/83, Działalność duszpasterska, obchody „Millenium”, uroczystości kościelne na terenie miasta Krakowa i województwa, Ocena uroczystości kościelnych w Krakowie w dniach 6-8 V 1966 r., 12 V 1966, Kraków (sporządzili A.P. i ET), k. 60. Zob. też: ibidem, Środowiskowe opinie o uroczystościach kościelnych 1000-lecia chrztu Polski na terenie m. Krakowa w dniach 6-8 V 1966, k. 64-65.

${ }^{60}$ AAW, SPP, 04/21, Komisja Główna Episkopatu Polski 1966 r., Protokół Komisji Głównej Episkopatu Polski z 30 VIII 1966, k. 72-73. Zob. też: E.K. Czaczkowska, op. cit., s. 391-392. 


\section{Podsumowanie}

Mimo zaangażowania wielu sił i środków władzom Polski „ludowej” nie udało się zrealizować szerszych planów związanych z marginalizacją uroczystości milenijnych. Rola obydwu bohaterów mojej analizy była w ich czasie bardzo istotna. Rzecz jasna ze względu na sprawowaną funkcję i autorytet, jakim się cieszył prymas, działania wymierzone w jego osobę i pozycje miały dla dygnitarzy partyjnych najwyższy priorytet. Okazały się one zasadniczo nieskuteczne. Przebieg uroczystości milenijnych dodatkowo wzmocnił pozycję kard. Wyszyńskiego w polskim Kościele i episkopacie. Działania struktur zajmujących się inwigilacją i antykościelnymi represjami nie doprowadziły również do wywołania sporu prymasa z nowym metropolitą krakowskim. Ponadto pomimo usilnych starań krakowskiego aparatu represji i miejscowego Wydziału ds. Wyznań obchody milenijne w archidiecezji krakowskiej okazały się znaczącym sukcesem abp. Wojtyły. Ich przebieg wzmocnił pozycję ordynariusza krakowskiego w polskim episkopacie i pokazał jego zdolności organizacyjne oraz nieustępliwość wobec działań władz partyjnych. Wydaje się, że obie te kwestie miały wpływ na szybka kreację kardynalska, która nastapiła już w 1968 r. Jak pokazały kolejne lata, wszelkie działania władz, obliczone na skłócenie dwóch polskich kardynałów, nie przyniosły większych efektów, mimo zaangażowania do tego celu ogromnej liczby funkcjonariuszy Służby Bezpieczeństwa i szeregu osobowych źródeł informacji.

\section{Streszczenie}

W powyższej analizie przedstawiony został pewien wycinek „milenijnej konfrontacji”, omówiono działania władz wobec dwóch wielkich postaci polskiego Kościoła: kard. Stefana Wyszyńskiego i abp. Karola Wojtyły. Rola obydwu hierarchów w przygotowywaniu i przeprowadzeniu obchodów milenijnych była zupełnie inna. Prymas to autor koncepcji oraz główny kreator działań kościelnych, podczas gdy we wzmiankowanym okresie bp/abp Wojtyła był jednym z ważnych wykonawców jego założeń, którego pozycja jednakże systematycznie się zwiększała. Szczególnie istotna w kontekście działań wobec obu hierarchów była aktywność władz związana z listem biskupów polskich do biskupów niemieckich, mająca na celu zdyskredytowanie prymasa i abp. Wojtyły. W $1966 \mathrm{r}$. władze używały wszelkich metod zmierzajacych do ograniczenia obchodów kościelnych, co zakończyło się fiaskiem w postaci wielkiego sukcesu polskiego Kościoła. Przebieg uroczystości milenijnych dodatkowo wzmocnił pozycję kard. Wyszyńskiego w polskim Kościele i episkopacie. Działania struktur zajmujących się inwigilacją i antykościelnymi represjami nie doprowadziły również do wywołania sporu prymasa z nowym metropolitą krakowskim. Ponadto pomimo usilnych starań krakowskiego aparatu represji i miejscowego Wydziału ds. Wyznań obchody milenijne w archidiecezji krakowskiej wypadły okazale. 


\section{Card. Wyszyński and Abp Wojtyła in the Millennial 'Game' of the People’s Poland Authorities}

The above analysis presents a particular fragment of 'millennial confrontation', i.e. it discusses the Polish state authorities' actions against two significant figures of the Catholic Church in Poland: Cardinal Stefan Wyszyński and Archbishop Karol Wojtyła. The role of these two hierarchs in the preparations and implementation of the millennium celebrations was utterly different. The Primate was the author of the concept and the leading creator of Church activities. At the same time, Bishop/Archbishop Wojtyła, whose position was systematically increasing, was one of his projects' important executors. Particularly significant in the context of the actions against both hierarchs was the authorities' activity related to the letter of reconciliation of the Polish bishops to the German bishops, aimed at discrediting Card. Wyszyński and Abp Wojtyła. In 1966, the state authorities used all methods to limit Church celebrations, which ended in a fiasco in the form of the Polish Church's great success. The course of the millennium celebrations also strengthened Card. Wyszyński's position in the Polish Church and Episcopate. The activities of the structures dealing with surveillance and anti-Church repressions did not lead to a dispute between the Primate and the new Krakow Metropolitan. What is more, despite the Krakow repression apparatus's strenuous efforts and the local Department for Religious Affairs, the millennium celebrations in the Archdiocese of Krakow turned out to be splendid.

\section{Bibliografia}

Chmiel A., Prasa krajów socjalistycznych o Orędziu biskupów polskich do biskupów niemieckich i obchodach Millenium, w: Millennium polskie. Walka o rzad dusz, Warszawa 2002 , s. $150-166$.

Czaczkowska E.K., Kardynat Wyszyński. Biografia, Kraków 2013.

Dudek A., Gryz R., Komuniści i Kościót w Polsce 1945-1989, Kraków 2006.

Dudek A., Państwo i Kościót w Polsce 1945-1970, Kraków 1995.

Eisler J., Pusty tron, w: idem, Co nam zostało $z$ tamtych lat. Dziedzictwo PRL, Warszawa 2016, s. 195-206.

Gucewicz D., Próba sit? Rok 1966 w Gdańsku. Milenium kontra Tysiaclecie, Gdańsk 2014.

Janowski W., Orędzie biskupów polskich do biskupów niemieckich i obchody Tysiaclecia Chrztu Polski Państwowości Polskiej na tle stosunków państwo-Kościót w opiniach $i$ komentarzach zachodnich środków masowego przekazu, w: Millennium polskie. Walka o rzad dusz, Warszawa 2002, s. 121-149.

Komaniecka M., Inwigilacja Kościoła katolickiego przez SB podczas obchodów millenijnych w 1966 roku w Krakowie, ze szczególnym uwzględnieniem działalności Wydziatów pomocniczych „B”, „T”, „W”, w: Kościót katolicki w czasie komunistycznej dyktatury. Między bohaterstwem a agentura, t. II, red. R. Terlecki, J. Szczepaniak, Kraków 2008, s. $109-142$.

Kracik J., Krakowskie Millenium, w: Karol Wojtyta jako biskup krakowski, red. T. Pieronek, R.M. Zawadzki, Kraków 1998, s. 251-252.

Krawczak T., Orędzie biskupów polskich w ocenie struktur partyjnych i Stużby Bezpieczeństwa, w: Pojednanie i polityka. Polsko-niemieckie inicjatywy pojednania $w$ latach sześćdziesiatych XX wieku a polityka odprężenia, red. F. Boll, W.J. Wysocki, K. Zimmer, Warszawa 2010, s. 152-157.

Ku prawdzie i wolności. Komunistyczna bezpieka wobec kard. Karola Wojtyty, red. J. Marecki, F. Musiał, oprac. J. Marecki, M. Lasota, R. Szczęch, Kraków 2009. 
Lasota M., Donos na Wojtytę. Karol Wojtyła w teczkach bezpieki, Kraków 2006.

Lasota M., Dziatania aparatu PRL wobec kard. Karola Wojtyty w latach 1967-1978. Wybrane zagadnienia, w: Kościót katolicki w czasach komunistycznej dyktatury. Między bohaterstwem a agentura. Studia i materiały, t. III, red. J. Szczepaniak, M. Lasota, Kraków 2010 , s. $9-56$.

Lasota M., Małopolska, w: Milenium czy Tysiaclecie, red. B. Noszczak, Warszawa 2006, s. $196-213$.

Łatka R., Czy prymasa Wyszyńskiego możemy określać mianem realisty politycznego?, w: Realizm polityczny, red. R. Łatka, „Politeja” 2013, nr 25, s. 201-212.

Łatka R., Koniec odwilży w relacjach państwo-Kościót (1957-1958) z perspektywy Prymasa Stefana Wyszyńskiego, w: Christus vincit. Ksiega dedykowana Biskupowi Edwardowi Frankowskiemu $w$ 80. rocznicę urodzin, red. nauk. M. Krzysztofiński, J. Wołczański, Rzeszów 2017, s. 313-334.

Łatka R., Polityka władz Polski „ludowej” wobec Kościoła katolickiego w latach 1944-1979 (przypadek krakowski), „Zeszyty Historyczne WiN-u” 2014, nr 39, s. 175-188.

Łatka R., Polityka władz PRL wobec Kościoła katolickiego w województwie krakowskim w latach 1980-1989, Kraków 2016.

Łatka R., Rywalizacja państwo-Kościót w czasie obchodów millenijnych na przykładzie województwa krakowskiego, w: Pót wieku Milenium. Religijne, polityczne i społeczne aspekty obchodów tysiaclecia chrztu Polski. (1956-1966/1967). Studia i materiaty, red. B. Noszczak, Warszawa 2018, s. 679-705.

Madajczyk P., Na drodze do pojednania. Wokót orędzia biskupów polskich do biskupów niemieckich z 1965 roku, Warszawa 1994.

Madajczyk P., „Przebaczamy i prosimy o przebaczenie...”, „Więź” 1990, nr 9.

Marek Ł., „Kler to nasz wróg”. Polityka władz państwowych wobec Kościoła katolickiego na terenie województwa katowickiego w latach 1956-1970, Katowice 2009.

Marek Ł., Priorytety polityki wyznaniowej wtadz w okresie Gomutki, w: Priorytety polityki wyznaniowej władz Polski „ludowej”, red. R. Łatka, „Glaukopis” 2016, nr 32, s. 254-285.

Milenium czy Tysiaclecie, red. B. Noszczak, Warszawa 2006.

Millennium polskie. Walka o rzqd dusz, Warszawa 2002.

Musiał F., „Do wspótpracy z nami dobierać...” Pierwsze lata działalności Wydziału IV SB KW MO w Krakowie, w: idem, Raj grabarzy Narodu. Studia i materiaty do dziejów aparatu represji w Polsce „ludowej” 1945-1989, Kraków 2010, s. 280-309.

Natanek P., Obchody millenium $w$ archidiecezji krakowskiej, w: Studia i rozprawy ofiarowane profesorowi Tytusowi Górskiemu, Kraków 2003, s. 151-163.

Nitecki P., Prymas Tysiaclecia, w: W stużbie Boga i Polski. Komunistyczna bezpieka wobec kardynała Stefana Wyszyńskiego, red. J. Marecki, F. Musiał, oprac. J. Marecki, P. Nitecki, R. Szczypta-Szczęch, Kraków 2014, s. 9-23.

Noszczak B., „Sacrum” czy „profanum”? Spór o istotę obchodów Milenium polskiego (19491966), Warszawa 2002.

Obchody Millenium na Uchodźstwie. W 50. rocznicę, red. R. Łatka, J. Żaryn, Warszawa 2016.

Pót wieku Milenium. Religijne, polityczne i społeczne aspekty obchodów Tysiaclecia Chrztu Polski (1956-1966/1967). Studia i materiaty, red. B. Noszczak, Warszawa 2018.

Raina P., Kardynat Wyszyński. Konflikty roku milenijnego 1966, Warszawa 2000.

Raina P., „Te Deum” narodu polskiego. Obchody Tysiaclecia Chrztu Polski w świetle dokumentów kościelnych, Olsztyn 1991.

Ryś G., O krakowskie aggiogramento. Archidiecezja krakowska pod rzadami arcybiskupa Wojtyty (1963-1978), w: Kościót krakowski w tysiącleciu, Kraków 2000, s. 451-481.

Stępień S., Sobór Watykański II i orędzie Episkopatu Polski do biskupów niemieckich, w: Milenium czy Tysiqclecie, red. B. Noszczak, Warszawa 2006, s. 44-51. 
Szczepaniak J., „Wierny” aż do śmierci. Tajemna historia ks. Mieczystawa Satory, w: Kościót katolicki w czasach komunistycznej dyktatury. Między bohaterstwem a agenturq. Studia $i$ materiaty, t. I, red. J. Szczepaniak, R. Terlecki, Kraków 2007, s. 79-134.

Szot A., Sychowicz K., Białostockie millenium. Biatystok na millenijnym szlaku. Obchody tysiaclecia chrztu Polski (1966 r.), Białystok 2006.

Teczki Wojtyty, Kraków 2003.

W stużbie Boga i Polski. Komunistyczna bezpieka wobec kardynała Stefana Wyszyńskiego, red. J. Marecki, F. Musiał, oprac. J. Marecki, P. Nitecki, R. Szczypta-Szczęch, Kraków 2014.

Wokót orędzia. Kardynat Bolesław Kominek prekursor pojednania polsko-niemieckiego, red. W. Kucharski, G. Strauchold, Wrocław 2009.

Zapomniany rok 1966. WXXX rocznicę obchodów Milenium Chrztu Polski, red. L. Mażewski, W. Turek, Gdańsk 1996.

Zieliński Z., Wielka Nowenna na tle powojennych losów Kościoła w Polsce, w: Ecclesia Posnaniensis. Opuscula Mariano Banaszak septuagenario dedicata, Poznań 1998, s. 273-288. Żaryn J., Dzieje Kościoła katolickiego w Polsce (1944-1989), Warszawa 2003.

Rafał Latka - dr hab. historii, dr nauk politycznych, główny specjalista w Biurze Badań Historycznych Instytutu Pamięci Narodowej i Instytucie Dziedzictwa Myśli Narodowej im. Romana Dmowskiego i Ignacego Jana Paderewskiego. Zainteresowania naukowe: historia Kościoła katolickiego w XX w., komunizm, aparat represji, polska myśl polityczna w XX w. E-m a il: rafal.latka@ipn.gov.pl.

Rafal Latka - Dr. hab. of history, doctor of political science, chief specialist in the Historical Research Office and the Roman Dmowski and Ignacy Jan Paderewski Institute for the Heritage of National Thought. His scholarly interests cover: history of the Catholic Church in the 20th c., communism, repression apparatus, Polish political thought in the 20th c. E-m ail: rafal.latka@ipn.gov.pl. 